Feasibility of Using a Multiple Award Schedule for Specifying Paints in Government Painting Contracts

Mary E. McKnight 


\section{Feasibility of Using a Multiple Award Schedule for Specifying Paints in Government Painting Contracts}

Mary E. McKnight

November 1991

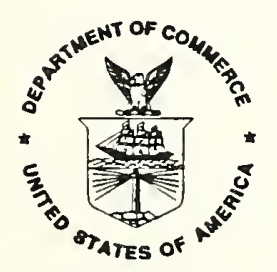

\section{U.S. Department of Commerce}

Robert A. Mosbacher, Secretary

National Institute of Standards and Technology

John W. Lyons, Director

Building and Fire Research Laboratory

Gaithersburg, MD 20899 
$-$ 
The Department of Defense is placing increasing emphasis on the use of commercially available or branded products in lieu of Military or Federal Specification products in building construction and maintenance. However, there are few industry consensus specifications for paints and coatings. Although non-government consensus coating specifications are being developed, a General Services Administration Federal Supply Schedule provides an additional mechanism through which Federal agencies can obtain commercially available coatings. Specifically, the use of a Multiple Award Federal Supply Schedule in a military painting contract is discussed in this report. Procedures for obtaining the lowest cost material that would meet the Government's minimum needs are addressed. A description of need based upon performance criteria for the specific end use, that would be included in a painting contract, is suggested. Advantages and disadvantages of using a Multiple Award Schedule in painting contracts are enumerated. Advantages include providing a mechanism for using new coating technology, taking advantage of manufacturer's technical support and knowledge of regulatory issues, and decreasing the need for revising or preparing new coating specifications. Disadvantages include the additional effort needed to revise guide specifications, train both coating users and suppliers in new procedures and the lack of performance criteria for some end uses. Despite the disadvantages cited, it is concluded that the advantages outweigh the disadvantages and that use of a Multiple Award Schedule in painting contracts is feasible.
\end{abstract}

KEYWORDS: Contracts, Multiple Award Schedule; painting; performance critiera, contracts 
1. INTRODUCTION ........................ 1

2. GENERAL DESCRIPTION OF MULTIPLE AWARD SCHEDULE $\ldots \ldots \ldots \ldots$

2.1 Description of Multiple Award Schedule for Latex Paints . . . . . . . . 2

2.2 Recommendations on Use of Multiple Award Schedules .......... 2

3. USE OF MULTIPLE AWARD SCHEDULES IN PAINTING CONTRACTS . . . . 2

3.1 Determining Job-Specific Requirements . . . . . . . . . . . . . . 3

3.1.1 Examples Using Latex Multiple Award Schedule . . . . . . . . . . 3

3.2 Application to a Guide Specification $\ldots \ldots \ldots \ldots \ldots \ldots$

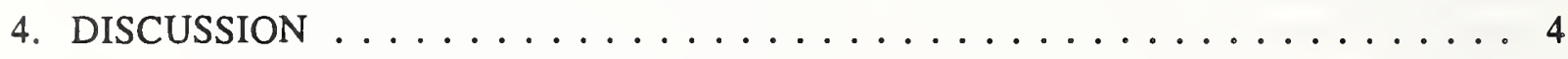

5. CONCLUSIONS AND RECOMMENDATIONS .............. 5

6. ACKNOWLEDGEMENTS ..................... 6

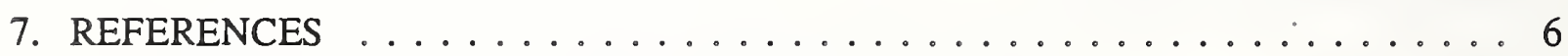




\section{INTRODUCTION}

During the past few years, the Department of Defense (DoD) has placed increased emphasis on the use of commercially available or branded products in lieu of military or Federal specification products in facility construction and maintenance [1]. For paints and coatings, the use of commercially available products has been limited because of the lack of industry or other non-government material specifications. There are no non-government coating specifications for residential paints and only a few for industrial paints. Further, some of these specifications are not appropriate for use in areas with volatile organic compound (VOC) content regulations.

Although efforts to write non-government consensus paint specifications are being supported by members of the Federal community, progress is slow. A General Services Administration (GSA) Federal Supply Schedule provides an additional mechanism which could be used to help Federal agencies obtain commercially available coatings. This mechanism is used by GSA to provide Federal agencies with many products and services. The objective of this report is to determine the feasibility of using a Multiple Award Federal Supply Schedule in conjunction with government painting contracts.

\section{GENERAL DESCRIPTION OF A MULTIPLE AWARD SCHEDULE}

A Multiple Award Schedules (MAS) is one of four types of Federal Supply Schedules [2]. The Federal Supply Schedule program, directed and managed by the General Services Administration, provides Federal agencies with a simplified process for obtaining commonly used, commercially available, supplies and services at prices associated with volume buying. Multiple award schedules cover contracts made with more than one supplier for comparable supplies and services. Contractors catalogs and price lists are used with the schedules to prepare delivery orders. For the products of the same generic type on a given schedule, the quality and cost may vary [2].

Consistent with the Competition in Contracting Act, Public Law 98-369, Federal Supply Schedules are competitive [3] in that:

a. All responsible sources are allowed to participate in negotiations.

b. Contracts are awarded to firms which meet the minimum needs of one or more Federal agencies. Each ordering agency is responsible for determining its minimum needs and placing an order with the Multiple Award Schedule contractor which can satisfy the need at the lowest cost.

c. The method of pricing and ordering against a Multiple Award Schedule guarantees that resultant contracts and orders constitute the lowest overall cost alternative to meet the minimum needs of the Government. Prices are negotiated based on the offeror's most favored customer discounts extended to commercial customers under terms and conditions similar to those established by the Multiple Award Schedule. 
d. Contract prices have been determined to be fair and reasonable based on the

Government's competitive position with the contractors, other customers and the prices of similar products of other suppliers.

GSA's procedures for developing a MAS meet Federal regulations for competition, synopsizing, determining fair and reasonable pricing, and meeting small business-small purchase set-asides [2]. Thus, according to 48 CFR 8.404, contracting officers need not further address these elements when placing an order under a MAS.

\subsection{Description of Multiple A ward Schedule for Latex Paints}

The General Services Administration has issued a MAS for paints, 10SC 8006, extending from May 1, 1988 to April 30, 1991, as shown in Appendix 1. Both interior and exterior architectural latex primers and finish coats are included. Three gloss levels are available for each type of finish coat. Primers for exterior use are also included. Sixteen to 17 interior products and 10 to 15 exterior products of each type are listed on the schedule. The availability of each product in each of the 13 geographic zones is defined. Both local and nation-wide suppliers have contracted with GSA to place their paints on the schedule.

Some material and material-related requirements have been placed on these products. They include a limit on lead content, prohibition of use of reclaimed halogenated aliphatic hydrocarbons, a method for determining fill, and submission of commercial catalogs or price lists, or both, which show established catalog or market prices (special catalogs printed for the purpose of the MAS are not acceptable).

\subsection{Recommendations on Use of Multiple Award Schedules}

In response to executive and congressional insistence to increase the use of commercial materials, as opposed to specification materials, the Office of The Secretary of Defense is urging procurement of commercial materials [4]. Use of the Federal Supply Schedule by DoD could help to meet this goal. Procedures for using a FSS were changed in 1991 to make the use of schedules easier and to increase the limit above which documentation is required when an order is placed for other than the lowest priced item [5]. The new limit above which justification for non-use of the lowest cost item is required is $\$ 2500$, or 10 percent of the small purchase threshold (48 CFR 1-13.106 [6]).

\section{USE OF MULTIPLE AWARD SCHEDULES IN PAINTING CONTRACTS}

Most of the paint used to maintain military facilities is purchased by a painting contractor rather than directly by the Government. $48 \mathrm{CFR}$, Ch. 1 Part 51 prescribes policies and procedures for the use of Government supply schedules by contractors [7]. Part 51.101 states, "If it is in the Government's interest, and if supplies or services required in the performance of a Government contract are available from Government supply sources, contracting officers may authorize contractors to use these sources . . in performing (1) 
Government cost-reimbursement contracts and (2) other types of negotiated contracts." Procedures authorizing use of Government supply sources by contractors are described in 48 CFR 51.102 [7].

In addition to these regulatory requirements, material requirements would also be required to ensure that a contractor purchased a material from the schedule that could be expected to meet the minimum needs of the government. A mechanism by which this could be accomplished is discussed below.

\subsection{Determining Job-Specific Requirements}

As stated above, according to the regulation 48 CFR 8.405 for orders in excess of $\$ 2500$, the ordering agent is required to buy the material having the lowest delivered price available on a schedule unless a justification can be made that the material does not meet the need. For orders less than $\$ 2500$, no justification is needed to order a material other than the one having the lowest cost. Justifications for not ordering the lowest cost item can be based on delivery time, special requirements (e.g, environmental regulations), compatibility with existing systems, and special features offered by a product that are required for effective program performance [2]. Thus, materials other than the lowest price could be obtained when there are job-specific requirements that are not met by the lowest price material.

Currently, job-specific requirements enter into a painting contract through material and guide specifications. Although these are not stated specifically in manuals or guide specifications, they are alluded to in guide specifications by recommending particular material specifications for specific end uses. In addition, guidelines for performance requirements developed by non-government associations and the coating industry can also be drawn upon to develop jobspecific requirements. Thus, information is available to prepare job-specific requirements.

\subsubsection{Examples Using The Latex Paint Multiple Award Schedule}

The Multiple Award Schedule for latex paints describes end use according to interior or exterior, primer or topcoat, and gloss level. To obtain material that would meet specific job requirements (which may not necessarily be obtained from the lowest cost material), additional performance requirements would be needed, based upon the end use. For example, if a family room were to be painted, easy removal of soil and stains would be essential and a low gloss paint may be desired. Hence, a specific requirement for excellent scrubbability and low gloss level would be included in the requirements. However, if the paint were being used to restore the appearance of a concrete warehouse, a material with good hiding would be essential and scrubbability would be of lesser importance. In this case, a requirement for one-coat hiding would be included in the requirements. 


\subsection{Application to a Guide Specification}

Most military facility painting is done under a painting contract prepared using information obtained from a military guide specification. For example, the Navy specification is NFGS 09910 for painting of military facilities, while the Army specificaition is CEGS 09900. (A revision of the current documents is being developed by all three services and will be presented for consideration as a Tri-Service Specification). Currently, the guide specifications recommend coatings based upon Federal or military specification coatings. Particular specifications are chosen by people preparing the guide specifications to meet the intended end use. The expected performance of the material is based primarily upon experience with a given prescriptive formulation specification (the required formulation is given in the material specification) or the performance requirements in a coating specification. If materials from a MAS were to be used in a painting contract, a different procedure for specifying material requirements would be needed, since the lowest cost material may not meet the job requirements. One possibility would be to develop a set of general and specific requirements for various end uses. General requirements would be those expected of all coatings and would include such factors as application, drying and curing properties. Specific requirements would be directly related to end use and provide a mechanism of specifying high-performance coatings, if needed, or low-cost, limited service life material, if desired. Another possible procedure for specifying material requirements would be to require that a material meet a given material specification. Consensus, nongovernment specifications would be the preferred type of specification, since they often describe commercially available materials and do not rely upon Government staff to maintain.

As illustrated above, there are several feasible possibilities for including performance requirements in guide specifications and painting contracts. The major disadvantage in changing from material specifications to performance requirements would be the effort needed to revise the documents and train personnel in their use.

\section{DISCUSSION}

The use of MAS in government contracts is possible under the current Code of Federal Regulations (48 CRF 1-51.102). Advantages of using the MAS to procure materials in lieu of Federal and Military Specifications in situations in which there are no military-unique requirements include:

- reducing reliance on military and Federal paint specifications as encouraged by the Federal Government

o providing a mechanism for using commercially available materials

o stimulating development and use of sound performance criteria 
o making use of paint manufacturer's responsibility for and knowledge of procedures for complying with environmental regulations

o facilitating the use of new technology

o decreasing the need for new or revised specifications

o obtaining benefits associated with brand name

o improving technical support from a contractor.

On the other hand, there are disadvantages. These include:

o implementation would require substantial revision of guide specifications and training for both suppliers and users

o resolution of painting problems may be more difficult

o performance criteria have not been completely developed for some end uses.

Overall, the advantages appear to out weigh the disadvantages, particularly in encouraging innovation and promoting the performance concept. The major efforts required to implement the use of MAS in painting contracts would be to develop performance-based job specific coating requirements and train the staff in the use of revised guide specifications. It is anticipated that once the initial work to revise the guide specifications and train the staff had been completed, the amount of effort to maintain the system would significantly decrease.

\section{CONCLUSIONS AND RECOMMENDATIONS}

Based upon this study, it is concluded that there appear to be important advantages in using a Multiple Award Schedule in specifying coatings in painting contracts, although rather major changes in current procedures and documents would be required. Documents would need to be revised and training design and contracting staffs, as well-as suppliers of coatings, would be required. However, it is concluded that the use of Multiple Award Schedules in facility painting contracts is feasible. It is recommended that, as a first step, material performance criteria for specific end uses be developed. This is an essential step to assure that the coating obtained from a MAS will meet the user's need. 


\section{ACKNOWLEDGEMENTS}

This investigation was conducted under the sponsorship of the Tri-Services Facilities Coatings Committee with joint sponsorship by the US Army, Engineering Housing Services Center; US Navy, Naval Facilities Engineering Command; and US Air Force, Air Force Engineering and Services Center.

\section{REFERENCES}

1. OMB circular A-119, "Federal participation in the development and use of voluntary standards," U.S. Office of Management and Budget, 1982.

2. Federal Acquisition Regulation (FAR); Required sources of supplies and services, Code of Federal Regulations, 48 CFR Part 8.

3. Federal Supply Schedule, Multiple Award, 10SC 8006, FSC Group 80, Part VI, Section A, FSC Class 8010, Paint, Latex, Interior and Exterior, August 17, 1988.

4. Director's Message, Standardization and Data Management Newsletter, Department of Defense, Defense Quality and Standardization Office, Falls Church, VA, July 1990.

5. Federal Acquisition Regulation (FAR); Quality and contractor responsibility, Code of Federal Regulations, 48 CFR 8.405-1.

6. Federal Acquisition Reguation (FAR); "Contracting methods and contract types, Small and other simplified purchase procedures," 48 CFR 13.106.

7. Federal Acquisition Regulation (FAR); Use of Government sources by Contractors, 48 CFR 1-51. 
Appendix 1. Multiple Award Federal Supply Schedule, FSC Group 80 Part VI Section A, FSC Class 8010, Paint, Latex, Interior and Exterior, 10 SC 8006, August 17, 1988 


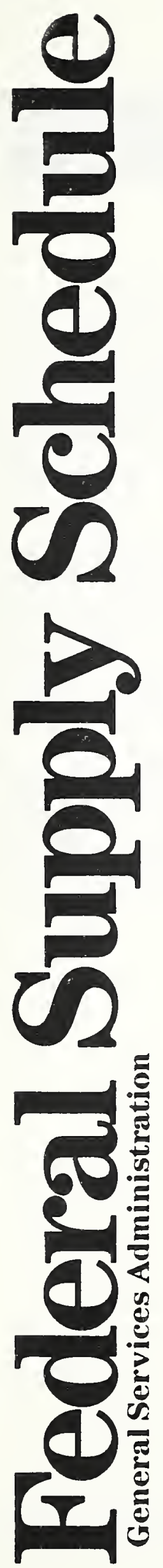

\section{Cumulative Edition}

September 11, 1991

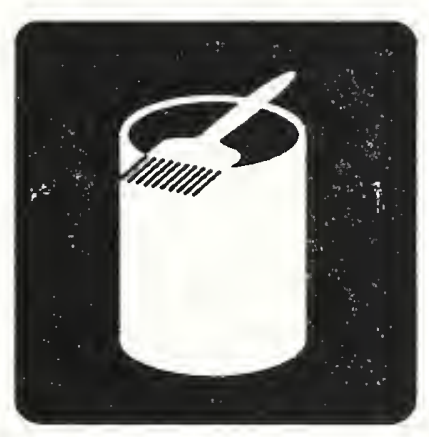

Paint, Latex, Interior and Exterior

Latex Paint, Gloss, Semigloss and Flat, Tint Bases and Ready-Mixed Colors and Latex Primer Sealer

\begin{tabular}{ll}
\hline FSC Group & $\mathbf{8 0}$ \\
Part & VI \\
Section & A \\
FSC Class & $\mathbf{8 0 1 0}$ \\
\hline
\end{tabular}

Multiple Award

For the period

May 1, 1991

through

April 30, 1996

This document replaces the

Basic Edition issued

May 24, 1991. 


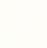




\section{HOW TO GET ASSISTANCE}

\section{SIGNIFICANT CHANGES}

\section{GSA CONTACTS}

\section{Contracting Officer}

General Services Administration

Contracting Officer (9FTP-10-C-M)

(FSC Group 80 Part VI Section A)

GSA Center

Aubum, WA 98001

COM: (206) 931-7937

FTS: 396-7937

For Additional Copies of Schedules

General Services Administration

Centralized Mailing List Service (7CAFL)

4900 Hemphill St

Warehouse 4, Dock 1

PO Box 6477

Fi: Worth, TX 76115

(COM)FTS: (817) 334-5215

AUTOVON: $739-7369$

For General Information General Services Administration

FSS Information Center (FFN)

Washington, DC 20406

(COM)FTS: (703) 557-8177

AUTOVON: 225-9684

\section{FAX NUMBER ADDITION}

The Devoe \& Raynolds Co now has the following FAX number: (502) 893-1444.

\section{ADDITIONAL AWARDS}

DEL Paint Corp

Fanwest Paint Mfg Co

The Glidden Co

Hyklas Paints Inc

PPG - Pittsburgh Paint

The Sherwin Williams Co 


\section{GENERAL INFORMATION}

\section{GEOGRAPHIC COVERAGE}

This schedule covers the 48 contiguous states and Washington, DC; also Alaska, Hawaii and Puerto Rico, if indicated in the contractor's price list.

\section{MANDATORY USERS}

All departments and independent establishments, including wholly owned government corporations, in the executive branch of the federal government except DOD and the US Postal Service.

\section{INCORPORATION OF FORMS}

Federal Supply Schedules incorporate the following form(s) containing provisions and/or contract clauses by reference, with the same force and effect as if they were included in full text. Upon request, the contracting officer will make the forms available. Questions concerning the forms should be directed to the contracting officer.

GSA Form 2891, Federal Supply Schedule clauses GSA Form 3507, GSA Supply Contract clauses

\section{PUBLICIZING CONTRACT ACTIONS}

The solicitation and resulting contracts of this Federal Supply Schedule have been synopsized in the Commerce Business Daily and satisfy the requirements of the Competition in Contracting Act (Pub L 98 369) and FAR Part 5, Publicizing Contract Action.

\section{ORDERING INFORMATION}

Ordering offices should review this schedule to determine: Special Item Numbers, item names and descriptions, contractor addresses and telephone numbers and contract numbers and contract effective dates.

\section{Small Requirements/Minimum Order}

See contractor's catalog/price list under "Small Requirements" for the lowest value order that will be accepted. Notwithstanding the above, it is optional on the government to place orders below $\$ 300$ with the schedule contractor. However, the contractor is obligated to accept any order beween the minimum and maximum order limitations.

\section{Colorants and Formula Booklets}

Colorants and Formula Booklets are available from the following firms:

Devoe \& Raynolds Co

Farwes: Paint Mfg Co

The Glidden Co

Hyklas Paints Inc

The Sherwin Williams Co

\section{Payment by Credit Card}

Definitions. "Government Commercial Credit Card" means the uniquely numbered credit card issued by the contractor under single award schedule, Federal Supply Schedule IG 615, Governmentwide Commercial Credit Card Service, to named individual government employees to pay for official government purchases.

"Oral delivery order" means an order placed orally, either in person or by telephione, which is paid for by government commercial credit card.

At the option of the government and if agreeable to the contractor, payments of $\$ 25,000$ or less for oral or written delivery orders may be made using the government commercial credit card.

The contractor shall not process a transaction for payment through the credit card clearinghouse until the purchased supplies have been shipped or services performed. Unless the cardholder requests correction or replacement of a defective or faulty item in accordance with other contract requirements, the contractor shall immediately credit a cardholder's account for items retumed as defective or faulty. 


\section{DELIVERY ZONES}

\section{SUPPLIES AND/OR SERVICES}

For the purpose of this schedule, zones consist of geographic areas specified below. See the "Contractors" section to determine which zones were awarded to each individual contractor.

\section{Zone 1}

Connecticut, Maine, Massachusetts, New Hampshire, Rhode Island and Vermont.

\section{Zone 2}

New Jersey and New York.

\section{Zone 3}

Delaware, Maryland, Pennsylvania, Virginia, Washington, DC and West Virginia.

\section{Zone 4}

Alabama, Florida, Georgia, Kentucky, Mississippi, North

Carolina, South Carolina and Tennessee.

Zone 5

Illinois, Indiana, Michigan, Minnesota, Ohroand Wisconsin.

\section{Zone 6}

lowa, Kansas, Missouri and Nebraska.

\section{Zone 7}

Arkansas, Louisiana, New Mexico, Oklahoma and Texas.

\section{Zone 8}

Colorado, Montana, North Dakota, South Dakota, Utah and Wyoming.

\section{Zone 9}

Arizona, California and Nevada.

\section{Zone 10}

Idaho, Oregon and Washington.

\section{Zone 11}

Hawaii.

\section{Zone 12}

Alaska.

\section{Zone 13}

Puerto Rico and the Virgin Islands.

\section{Commodity Listing Information \\ Index Numbers. \\ Special Item Numbers. \\ Descriptions.}

Brand names and awarded contractors. Brand names are listed alphabetically on the left, with contractors listed in boldface immediately following on the right. For example:

Brand Name-Contractor

See "Contractors" section for complete contractor names, addresses, telephone numbers, contract numbers and contract effective dates.

New contractors are listed in italic.

\section{INTERIOR LATEX PAINT}

\section{$1536-1$}

Flat

Classic 99- The Sherwin Williams Co

Farwest-Farwest Paint Mfg Co

Hyklas - Hyklas Paints Inc

Speedcrat -PPG-Pittsburgh Paint

Speedhide-PPG-Pittsburgh Paint

Speedpro-PPG-Pittsburgh Paint

Spred Satin-The Glidden Co

Spred Ultra - The Glidden Co

Super Paint-The Sherwin Williams Co

Super Supreme-DEL Paint Corp

Ultra-Hide - The Glidden Co

Wallhide-PPG-Pittsburgh Paint

Wonder-Tones 36XX-Devoe \& Raynolds Co

Wonder-Speed 505XX-Devoe \& Raynolds Co

\section{$2536-2 a$}

Semigloss

Akua-DEL Paint Corp

Classic 99-The Sherwin Williams Co

De-Vo-Ko-Devoe \& Raynolds Co

Farwest - Farwest Paint Mfg Co

Promar 200-The Sherwin Williams Co

Promar 400-The Sherwin Williams Co

Satinhide-PPG-Pittsburgh Paint

Speedcraft - PPG-Pittsburgh Paint

Spred Enamel-The Glidden Co

Spred Ultra - The Glidden Co

Super Paint - The Sherwin Williams Co

Ultra-Hide - The Glidden Co

Wonder-Speed 525XX-Devoe \& Raynolds Co 
$3 \quad 536-2 b$

Acrylic Semigloss

Fanwest-Fanwest Paint Mfg Co

Hyklas-Hyklas Paints Inc

Speedhide-PPG-Pittsburgh Paint

Speedpro-PPG-Pittsburgh Paint

Wonder-Tones 38XX-Devoe \& Raynolds Co

\section{$4 \quad 536-3 a$ \\ Gloss}

Akua-DEL Paint Corp

Fanwest-Fanwest Paint Mfg Co

PPG-PPG-Pittsburgh Paint

Promar 200-The Sherwin Williams Co

\section{$5 \quad 536-3 b$}

Acrylic Gloss

Fanwest-Farwest Paint Míg Co

$13 \times \times$ Series - The Glidden Co

\section{$6536-4$}

\section{Primer}

Fanwest-Farwest Paint Mfg Co

Hyklas - Hyklas Paints Inc

Promar 200-The Sherwin Williams Co

Promar 400-The Shenwin Williams Co

PVA-DEL Paint Corp

Speedcraft-PPG-Pittsburgh Paint

Speeohide-PPG-Pittsburgh Paint

Spred-The Glidden Co

Ultra-Hide - The Glidden Co

Wonder-Tones 50801 - Devoe \& Raynolds Co

Wonder-Speed 55201 - Devoe \& Raynolds Co

\section{EXTERIOR LATEX PAINT}

\section{$7 \quad 536-5$ \\ Flat}

A-100-The Sherwin Williams Co

DEL-DEL Paint Corp

Endurance - The Glidden Co

Fanwest-Farwest Paint Mfg Co

Hyklas - Hyklas Paints Inc

Pitt-Cryl-PPG-Pittsburgh Paint

Speedhide-PPG-Pittsburgh Paint

Spred-The Glidden Co

Spred Uitra - The Glidden Co

Sun-Proof-PPG-Pittsburgh Paint

Super Paint - The Sherwin Williams co

Wonder-Shield $15 X X$ - Devoe \& Raynolds Co

Wonder-Guard 20XX-Devoe \& Raynolds Co
$8 \quad 536-6 a$

Semigloss

Akua-DEL Paint Corp

Fanvest-Farwest Paint Mfg Co

Speedhide-PPG-Pittsburgh Paint

$9 \quad 536-6 b$

Acrylic Semigloss

A-100-The Sherwin Williams Co

Fanwest-Farwest Paint Mfg Co

Hyklas-Hyklas Paints Inc

Spred-The Glidden Co

Spred Ultra - The Glidden Co

Sun-Proof-PPG-Pittsburgh Paint

Super Paint-The Sherwin Williams Co

Wonder-Shield 16XX-Devoe \& Raynolds Co

$10 \quad 536-7 a$

Gloss

AkUa-DEL Paint Corp

Fanwest-Fanwest Paint Mfg Co

PPG-PPG-Pittsburgh Paint

$11 \quad 536-7 b$

Acrylic Gloss

A-100 - The Sherwin Williams Co

Fanwest - Farwest Paint Mfg Co

Hyklas - Hyklas Paints Inc

Spred-The Glidden Co

Spred Ultra - The Glidden Co

Super Paint - The Sherwin Williams Co

Wonder-Shield $18 X X$ - Devoe \& Raynolds Co

\section{$12536-8$}

Primer

A-100-The Sherwin Williams Co

DEL-DEL Paint Corp

Fanwest-Farwest Paint Mfg Co

Hyklas-Hyklas Paints Inc

Speedhide - PPG-Pittsburgh Paint

Sun-Proof-PPG-Pittsburgh Paint

3690 - The Glidden Co

Wonder-Shield 1502-Devoe \& Raynolds Co

Wonder-Guard 2002-Devoe \& Raynolds Co 


\section{CONTRACTORS}

\section{Award Information}

- Contractor's name, address and telephone number.

- Business Size and Minority Business Enterprise indicators: "s" for small business, "o" for other than small business, "a" for minority business enterprises, "b" for other than minority business enterprises and " $w$ " for woman owned.

Delivery zones.

Pittsburgh Paint

1 PPG PI

Pittsburgh, PA 15272

(412) 434-2252

FAX: (412) 434-2125

Zones 1 through 13

o/b GS-10F-74834 3 Jul 91

The Sherwin Williams Co

101 Prospect Ave NW

Cleveland, $\mathrm{OH}$ 44115-1075

(216) 566-2030

FAX: (216) 566-1392

Zones 1 through 13

O/b GS-10F-7442A 4 Jun 91

Contract number and contract effective date.

New contractors are listed in italic.

\section{DEL Paint Corp}

3105 E Reno

Oklahoma City, OK 73117

(405) 672-1431

FAX: (405) 672-0804

Zones 1 through 10

s/b GS-10F-74684 24 Jun 91

Devoe \& Raynolds Co

A Div of Grow Group Inc

4000 Dupont Cir

Louisville, KY 40207

(502) 897-9861

FAX: (502) 893-1444

Zones 1 through 8 and 13

o/b GS-10F-7406A 1 May 91

\section{Farwest Paint Mfg Co}

4522 S 133rd St

Tukwila, WA 98168

(206) 244-8844

FAX: (206) 246-7691

Zones 1 through 10

s/b GS-10F-7512A $26 \mathrm{Jul} 91$

The Glidden Co

925 Euclid Ave

Cleveland, $\mathrm{OH} 44115$

(216) 344-8208

FAX: (216) 344-8900

Zones 1 through 13

o/b GS-10F-7490A $18 \mathrm{Jul} 91$

Hyklas Paints Inc

PO Box 3607

Louisville, KY 40201-3607

(502) 634-9406

FAX: (502) 637-8326

Zones 1 through 13

s/b GS-10F-7535A 16 Aug 91 


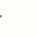




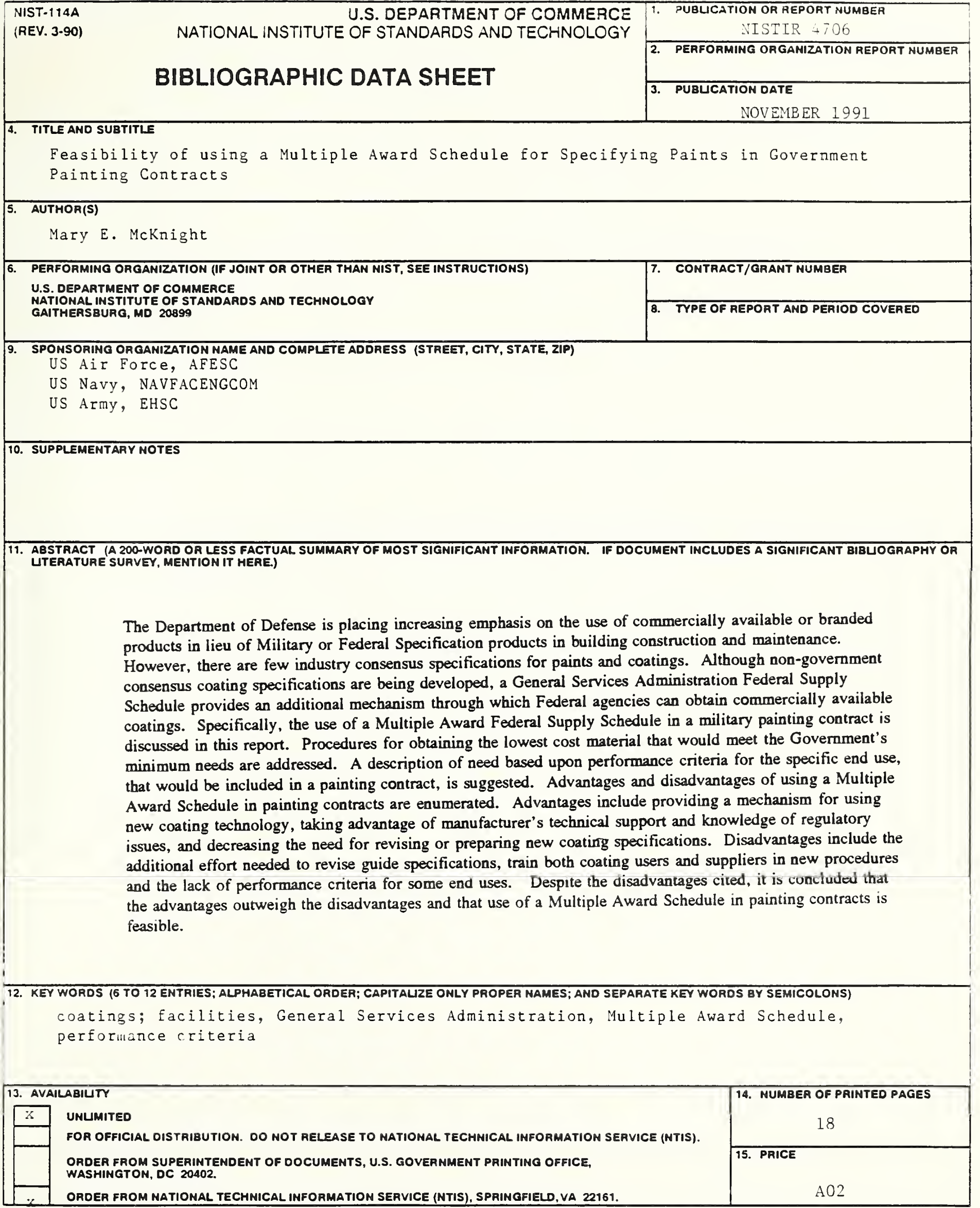




\section{-}


